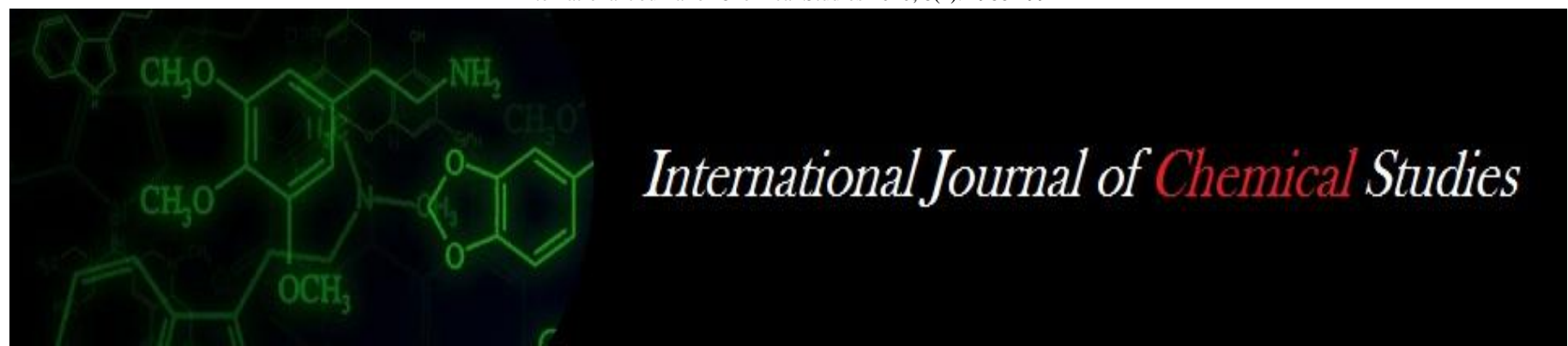

P-ISSN: 2349-8528

E-ISSN: 2321-4902

IJCS 2020; 8(1): 1988-1991

(C) 2020 IJCS

Received: 24-11-2019

Accepted: 28-12-2019

Yashaswini NP

Department of Plantation,

Spices, Medicinal and Aromatic

Crops, College of Horticulture,

University of Horticultural

Sciences, Bagalkot, Karnataka, India

\section{Vijaymahantesh VP}

Department of Agronomy,

College of Horticulture,

University of Horticultural

Sciences, Bagalkot, Karnataka,

India

\section{Singh VP}

Department of Plantation, Spices, Medicinal and Aromatic Crops, College of Horticulture, University of Horticultural Sciences, Bagalkot, Karnataka, India

\section{Kattimani}

Hon'ble Chairman and Vice-

Chancellor, University of

Agricultural Sciences, Raichur,

Karnataka, India

\section{Rudresh DL}

Department of Agricultural

Microbiology, College of

Horticulture, University of

Horticultural Sciences, Bagalkot,

Karnataka, India

MD Jameel Jhalegar

Department of Post Harvest

Technology, College of

Horticulture, University of

Horticultural Sciences, Bagalkot, Karnataka, India

\section{Corresponding Author:}

Yashaswini NP

Department of Plantation,

Spices, Medicinal and Aromatic

Crops, College of Horticulture,

University of Horticultural

Sciences, Bagalkot, Karnataka,

India

\section{Effect of integrated nutrient management on growth and yield of tulsi (Ocimum sanctum L.) in northern dry zone of Karnataka}

\author{
Yashaswini NP, Vijaymahantesh VP, Singh VP, Kattimani, Rudresh DL \\ and MD Jameel Jhalegar
}

DOI: https://doi.org/10.22271/chemi.2020.v8.i1ac.8557

\begin{abstract}
The field experiment entitled "Effect of integrated nutrient management on growth and yield of Tulsi (Ocimum sanctum L.) in Northern Dry Zone of Karnataka" was conducted during Kharif season of 201819. The experiment was laid out in RCBD with 10 treatments in 3 replications. The integrated nutrient management treatments selected for study comprised of $\mathrm{T}_{1}$ :Control - RDF $\left(125: 75: 60, \mathrm{~N}: \mathrm{P}_{2} \mathrm{O}_{5}: \mathrm{K}_{2} \mathrm{O} \mathrm{kg}\right.$ $\left.\mathrm{ha}^{-1}+\mathrm{FYM} 10 \mathrm{t} \mathrm{ha}^{-1}\right), \mathrm{T}_{2}: \mathrm{RD}$ of NPK $\left(125: 75: 60 \mathrm{~N}: \mathrm{P}_{2} \mathrm{O}_{5}: \mathrm{K}_{2} \mathrm{O} \mathrm{kg} \mathrm{ha}{ }^{-1}\right)+$ Vermicompost $5 \mathrm{tha}^{-1}, \mathrm{~T}_{3}: 75$ $\% \mathrm{RDN}+\mathrm{RD} \mathrm{P}_{2} \mathrm{O}_{5}$ and $\mathrm{K}_{2} \mathrm{O}+\mathrm{FYM} 10 \mathrm{t} \mathrm{ha}^{-1}+$ Azospirillum $10 \mathrm{~kg} \mathrm{ha}^{-1}, \mathrm{~T}_{4}: 75 \% \mathrm{RDN}+\mathrm{RD} \mathrm{P}_{2} \mathrm{O}_{5}$ and $\mathrm{K}_{2} \mathrm{O}+$ Vermicompost $5 \mathrm{t} \mathrm{ha}^{-1}+$ Azospirillum $10 \mathrm{~kg} \mathrm{ha}^{-1}$, $\mathrm{T}_{5}: \mathrm{T}_{3}+$ Azotobacter $10 \mathrm{~kg} \mathrm{ha}^{-1}, \mathrm{~T}_{6}: \mathrm{T}_{4}+$ Azotobacter $10 \mathrm{~kg} \mathrm{ha}^{-1}, \mathrm{~T}_{7}: 50 \% \mathrm{RDN}+\mathrm{RD} \mathrm{P}_{2} \mathrm{O}_{5}$ and $\mathrm{K}_{2} \mathrm{O}+\mathrm{FYM} 10 \mathrm{t} \mathrm{ha}^{-1}+$ Azospirillum $10 \mathrm{~kg} \mathrm{ha}^{-1}$, $\mathrm{T}_{8}: 50 \% \mathrm{RDN}+\mathrm{RD}_{2} \mathrm{O}_{5}$ and $\mathrm{K}_{2} \mathrm{O}+$ Vermicompost $5 \mathrm{t} \mathrm{ha}^{-1}+$ Azospirillum $10 \mathrm{~kg} \mathrm{ha}^{-1}, \mathrm{~T}_{9}: \mathrm{T}_{7}+$ Azotobacter $10 \mathrm{~kg} \mathrm{ha}^{-1}$ and $\mathrm{T}_{10}$ : $\mathrm{T}_{8}+$ Azotobacter $10 \mathrm{~kg} \mathrm{ha}^{-1}$. The results from the study revealed that application of $75 \% \mathrm{RDN}+\mathrm{RD} \mathrm{P}_{2} \mathrm{O}_{5}$ and $\mathrm{K}_{2} \mathrm{O}+$ Vermicompost $5 \mathrm{t} \mathrm{ha}^{-1}+$ Azospirillum $10 \mathrm{~kg} \mathrm{ha}^{-1}+$ Azotobacter $10 \mathrm{~kg} \mathrm{ha}^{-1}\left(\mathrm{~T}_{6}\right)$ recorded significantly higher plant height $(91.83 \mathrm{~cm})$, number of branches per plant (46.77), leaf area per plant $\left(4700.20 \mathrm{~cm}^{2}\right)$, leaf area index per plant (2.61),CGR $\left(10.65 \mathrm{~g} \mathrm{~m}^{-2}\right.$ day $\left.^{-1}\right)$, AGR $\left(1.92 \mathrm{~g} \mathrm{day}^{-1}\right)$, fresh herbage yield (125.83 $\mathrm{g}$ plant $\left.^{-1}\right)$ and dry herbage yield $\left(74.35 \mathrm{~g} \mathrm{plant}^{-1}\right)$ were recorded in Tulsi (Ocimum sanctum L.) compared to other treatments.
\end{abstract}

Keywords: Ocimum sanctum L., INM, growth parameters

\section{Introduction}

Tulsi (Ocimum sanctum L.) distributed in entire Indian subcontinent, the species sanctum of the genus Ocimum grows in wide range rather than other species of this genus (Nadkararni and Nadkarni, 1976) ${ }^{[1]}$. Ocimum tenuiflorum L.f. is a synonymous name of Ocimum sanctum L. which belongs to family Lamiaceae (Satyavati et al., 1976) ${ }^{[2]}$, is a well-known medicinal plant and oftenly known as 'Tulsi' in Hindi and "Holy Basil" in English, this species is also known as Sri Tulsi and Tulsi plants with purple leaves known as Krishna Tulsi (Sarkar et al., 1994) ${ }^{[3]}$. It is an herbaceous sacred plant of the Hindus and is worshipped in both homes and temples. Ocimum sanctum L. is medicinal herb, distributed throughout the world; various medicinal properties have been observed in Ocimum sanctum L. according to Mandal et al., $1993^{[4]}$. The genus ocimum is an extremely versatile group composed of 160 species with a geographic distribution spread over the tropical, sub-tropical and temperate regions of both the hemisphere ranging from sea level to $1800 \mathrm{ft}$. Leaves and tender parts of the shoots are economic parts of this crop.

In India it is cultivated on commercial scale and it is grown in various states of the countries like West Bengal, Maharashtra, Uttar Pradesh, Madhya Pradesh, Bihar, Jammu, Assam (Darrah, 1980) ${ }^{[5]}$. Apart from India, it is also cultivated in Asia and Africa, Egypt, France, Hungary, Italy, Morocco, and USA.

In indigenous system of medicine, different parts (leaves, stem, flower, root, seeds and even whole plant) of Ocimum sanctum L. have been recommended to cure various ailments like bronchitis, malaria, diarrhoea, dysentery, skin disease, arthritis, eye diseases, insect bites and soon.

The extract from fresh leaves and stem of Ocimum sanctum yield some phenolic compounds such as cirsilineol, circimaritin, isothymusin, apigenin and rosameric acid and appreciable 
quantities of eugeno. The leaves of Ocimum sanctum contain $0.7 \%$ volatile oil comprising about $71 \%$ eugenol and $20 \%$ methyl eugenol (Devi et al., 2001) ${ }^{[6]}$.

The integrated nutrient management system involves judicious combination of inorganic fertilizers and organic manures in building soil fertility and to improve the production potential of any crop (Khalid et al., 2015) ${ }^{[7]}$. Besides this approach is reasonably cheap, technically sound and practically feasible and is capable of maintaining the sustainability in production. Keeping this view the experiment was adopted to study the "Effect of integrated nutrient management on growth and yield of Tulsi (Ocimum sanctum L.) in Northern dry zone of Karnataka" was carried out.

\section{Materials and Methods}

The field experiment was conducted at Main Horticultural Research and Extension Centre (MHREC), University of Horticultural Sciences, Bagalkot during Kharif season of 2018-19 which is situated in Northern Dry Zone of Karnataka (Zone-3) located at $16^{\circ} 10^{\prime}$ North latitude, 74²' East longitude and at an altitude of 542.0 meters above the mean sea level. The field selected for the experiment was well levelled and the soil texture of experimental filed was clayey in texture, slightly sodic in nature. The temperature, relative humidity and distribution of rainfall had their impact on crop growth and development. As per the meteorological data from January, 2018 to December, 2018 the mean temperature was $27.19{ }^{0} \mathrm{C}$ to $33.37{ }^{0} \mathrm{C}$, relative humidity 35.25 to 66.81 per cent and rain fall was $22.14 \mathrm{~mm}$. were recorded during the experimental period.

The experiment was laid out in RCBD with 10 treatments in 3 replications consisting of different sources of nutrients in combination with biofertilizers with recommended dose of fertilizers. $\mathrm{T}_{1}$ :Control - RDF (125:75:60, N: $\mathrm{P}_{2} \mathrm{O}_{5}: \mathrm{K}_{2} \mathrm{O} \mathrm{kg}$ ha ${ }^{1}+$ FYM $\left.10 \mathrm{t} \mathrm{ha}^{-1}\right), \mathrm{T}_{2}$ : RD of NPK (125:75:60 N: $\mathrm{P}_{2} \mathrm{O}_{5}: \mathrm{K}_{2} \mathrm{O}$ $\left.\mathrm{kg} \mathrm{ha}^{-1}\right)+$ Vermicompost $5 \mathrm{t} \mathrm{ha}^{-1}, \mathrm{~T}_{3}: 75 \% \mathrm{RDN}+\mathrm{RD} \mathrm{P}_{2} \mathrm{O}_{5}$ and $\mathrm{K}_{2} \mathrm{O}+\mathrm{FYM} 10 \mathrm{t} \mathrm{ha}^{-1}+$ Azospirillum $10 \mathrm{~kg} \mathrm{ha}^{-1}, \mathrm{~T}_{4}: 75 \%$ $\mathrm{RDN}+\mathrm{RD} \mathrm{P}_{2} \mathrm{O}_{5}$ and $\mathrm{K}_{2} \mathrm{O}+$ Vermicompost $5 \mathrm{t} \mathrm{ha}^{-1}+$ Azospirillum $10 \mathrm{~kg} \mathrm{ha}{ }^{-1}, \mathrm{~T}_{5}: \mathrm{T}_{3}+$ Azotobacter $10 \mathrm{~kg} \mathrm{ha}^{-1}$, $\mathrm{T}_{6}: \mathrm{T}_{4}+$ Azotobacter $10 \mathrm{~kg} \mathrm{ha}^{-1}, \mathrm{~T}_{7}: 50 \% \mathrm{RDN}+\mathrm{RD} \mathrm{P}_{2} \mathrm{O}_{5}$ and $\mathrm{K}_{2} \mathrm{O}+\mathrm{FYM} 10 \mathrm{t} \mathrm{ha}^{-1}+$ Azospirillum $10 \mathrm{~kg} \mathrm{ha}^{-1}, \mathrm{~T}_{8}: 50 \% \mathrm{RDN}$ $+\mathrm{RD} \mathrm{P}_{2} \mathrm{O}_{5}$ and $\mathrm{K}_{2} \mathrm{O}+$ Vermicompost $5 \mathrm{t} \mathrm{ha}^{-1}+$ Azospirillum $10 \mathrm{~kg} \mathrm{ha}{ }^{-1}, \mathrm{~T}_{9}: \mathrm{T}_{7}+$ Azotobacter $10 \mathrm{~kg} \mathrm{ha}^{-1}$ and $\mathrm{T}_{10}: \mathrm{T}_{8}+$ Azotobacter $10 \mathrm{~kg} \mathrm{ha}^{-1}$.

The whole experimental plot was brought to a fine tilth by repeated ploughings followed by harrowing by tractor drawn cultivator. Finally, it was levelled and divided into plots of required size $(3 \mathrm{~m} \times 3 \mathrm{~m})$ and number. The recommended dose of FYM (10 t/ha) was applied to each plot and incorporated well in the soil 10 days prior to sowing. Chemical fertilizers were applied as per the treatment according to package of practice. The biofertilizers like Azotobacter chroococcum and Azospirillum lipoferum were applied to soil at the rate of 10 kilogram per hectare by mixing with vermicompost through broadcasting at the time of sowing as per the treatments.

Seeds were sown on 4th August, 2018 through line sowing and after sowing of seeds they were covered with a layer of fine soil and field was given light irrigation immediately after sowing. Germination of seedling commences from 10 days of sowing and excess seedlings were thinned out 20 days after sowing manually by retaining one healthy seedling per hill. Weeding was done at periodic intervals to keep the field weed free. Subsequent irrigations were given as per the crop requirement based on soil moisture content. The crop will be ready for the harvest 120 days after sowing and crop is harvested at full bloom stage. five plants from each plot was used to calculate the average height of the plant, number of branches, leaf area $\left(\mathrm{cm}^{2}\right)$ was determined with LI-3100 Area Meter, leaf area index (LAI) was worked out by using the following formula.

$$
\text { LAI }=\frac{\text { Leaf area of the entire plant }\left(\mathrm{cm}^{2}\right)}{\text { Spacing provided }\left(\mathrm{cm}^{2}\right)}
$$

Crop growth rate (CGR) was calculated by using following formula.

$$
\mathrm{CGR}=\frac{\left(\mathrm{W}_{2}-\mathrm{W}_{1}\right)}{\left(\mathrm{t}_{2}-\mathrm{t}_{1}\right)} \times \frac{1}{\mathrm{~A}}
$$

Where, $\mathrm{W}_{1}=$ Dry weight $(\mathrm{g})$ of the plant at initial time $\left(\mathrm{t}_{1}\right)$, $\mathrm{W}_{2}=$ Dry weight $(\mathrm{g})$ of the plant at final time $\left(\mathrm{t}_{2}\right), \mathrm{A}=$ Land area $\left(\mathrm{m}^{2}\right)$.

Absolute growth rate (AGR) was calculated by using following formula.

$$
\mathrm{AGR}=\frac{\left(\mathrm{W}_{2}-\mathrm{W}_{1}\right)}{\left(\mathrm{t}_{2}-\mathrm{t}_{1}\right)}
$$

Where, $\mathrm{W}_{1}=$ Dry weight $(\mathrm{g})$ of the plant at initial time $\left(\mathrm{t}_{1}\right)$, $\mathrm{W}_{2}=$ Dry weight $(\mathrm{g})$ of the plant at final time $\left(\mathrm{t}_{2}\right)$.

After harvest fresh weight of herb is recorded and then the plants were left in the field for 2 days to sun dry and thereafter bundles were made. Fresh herbage yield per plant and dry herbage yield per plant was recorded.

\section{Results and Discussion}

Observations on plant height are presented in Table-1. Significantly highest plant height $(91.83 \mathrm{~cm})$ was recorded in $\mathrm{T}_{6}$ and treatments $\mathrm{T}_{5}(90.83 \mathrm{~cm}), \mathrm{T}_{10}(89.87 \mathrm{~cm}), \mathrm{T}_{9}(88.83$ $\mathrm{cm}), \mathrm{T}_{4}(87.83 \mathrm{~cm})$ and $\mathrm{T}_{8}(86.83 \mathrm{~cm})$ were on par with $\mathrm{T}_{6}$. The lowest plant height was found in $T_{1}(81.23 \mathrm{~cm})$. Higher plant height $(91.83 \mathrm{~cm})$ was recorded in $\mathrm{T}_{6}$ this may be due to integrated supply of nitrogen through fertilizers, vermicompost, along with nitrogen fixing bacterias (Azotobacter chroococcum and Azospirillum lipoferum) were found to have not only the ability to fix nitrogen, but also the ability to release phytohormones similar to gibberellic acid and indole acetic acid, which could stimulate plant growth, absorption of nutrients and photosynthesis results in higher plant height. The results are in accordance with the findings of Srivastava (2017) ${ }^{[8]}$ in kalmegh.

Observations on number of branches plant ${ }^{-1}$ are presented in Table-1. Significantly higher number of branches per plant (46.77) was noticed in $T_{6}$ and the treatments $T_{5}$ (45.73), $T_{10}$ (44.53), $\mathrm{T}_{9}$ (43.67), $\mathrm{T}_{4}$ (42.53) and $\mathrm{T}_{8}$ (41.50) were on par with $\mathrm{T}_{6}$. Lowest number of branches per plant was found in $\mathrm{T}_{1}$ (37.53). Maximum number of branches (46.77) per plant was recorded in $\mathrm{T}_{6}$ this may be due to balanced application of nutrients and higher nitrogen content in vermicompost and fertilizers elevate the synthesis of protein, which enable the plant to grow faster and stimulates apical growth as well as increases branches per plant (Rahman et al., 2014) ${ }^{[9]}$. Similarly application of biofertilizers enhanced vegetative growth because of increased cell division and cell elongation in the auxillary buds triggered by various activities and increased photosynthesis and growth promoting substances 
that increased the laterals due to arrest of apical dominance, which enhances number of branches per plant. Similar results were documented by Raina et al. (2013) ${ }^{[10]}$.

Observations on leaf area are presented in Table-1. Significantly higher leaf area $\left(4700.20 \mathrm{~cm}^{2}\right)$ was noticed in $\mathrm{T}_{6}$ and the treatments $\mathrm{T}_{5}\left(4600.97 \mathrm{~cm}^{2}\right), \mathrm{T}_{1}\left(4350.73 \mathrm{~cm}^{2}\right), \mathrm{T}_{9}$ $\left(4300.20 \mathrm{~cm}^{2}\right)$ and $T_{4}\left(4096.63 \mathrm{~cm}^{2}\right)$ were on par with $\mathrm{T}_{6}$. Lowest leaf area $\left(3216.77 \mathrm{~cm}^{2}\right)$ was observed in $T_{1}$. The increased leaf area in this present study may be due to presence of plant growth promoters like auxin and cytokinin in the exudates of earth warms and in association with microbes as reported in salvia (Kale et al., 1987) ${ }^{[11]}$.

Observations on leaf area index are presented in Table-1. Significantly higher leaf area index (2.61) was recorded in $\mathrm{T}_{6}$ and the treatments $\mathrm{T}_{5}(2.56), \mathrm{T}_{10}(2.42), \mathrm{T}_{9}(2.39)$ and $\mathrm{T}_{4}$ (2.27) were on par with $\mathrm{T}_{6}$. While treatments $\mathrm{T}_{1}(1.79)$ and $\mathrm{T}_{7}$ (1.89) produced lowest leaf area index. The experimental results indicated that LAI found to be higher (2.61) in $\mathrm{T}_{6}$. This was due to more number of branches, leaves and leaf area. The progressive increase in LAI and branches and leaf number throughout the crop growth period indicates inherent indeterminate character. The results are in line with the Parshar et al. (2011) ${ }^{[12]}$ in kalmegh.

Observations on CGR are presented in Table-1. Significantly higher CGR (10.65 $\mathrm{g} \mathrm{m}^{-2}$ day $\left.^{-1}\right)$ was recorded in $\mathrm{T}_{6}$ and the treatments $\mathrm{T}_{5}\left(10.03 \mathrm{~g} \mathrm{~m}^{-2}\right.$ day $\left.^{-1}\right), \mathrm{T}_{10}\left(9.96 \mathrm{~g} \mathrm{~m}^{-2}\right.$ day $\left.^{-1}\right), \mathrm{T}_{9}$ $\left(9.51 \mathrm{~g} \mathrm{~m}^{-2}\right.$ day $\left.^{-1}\right)$ and $\mathrm{T}_{4}\left(9.40 \mathrm{~g} \mathrm{~m}^{-2}\right.$ day $\left.^{-1}\right)$ were on par with $\mathrm{T}_{6}$. However, lowest CGR $\left(6.13 \mathrm{~g} \mathrm{~m}^{-2}\right.$ day $\left.^{-1}\right)$ was observed in $\mathrm{T}_{1}$. The increase in CGR might be due to higher dry matter accumulation in plants and transfer of photosynthates from source to sink which designate the grand growth period of Ocimum sanctum. Similar trend was observed by Rashmi (2013) ${ }^{[13]}$ in ashwagandha.

Observations on AGR are presented in Table-1. Significantly higher AGR (1.92 $\left.\mathrm{g} \mathrm{day}^{-1}\right)$ was recorded in $\mathrm{T}_{6}$ and the treatments $\mathrm{T}_{5}\left(1.80 \mathrm{~g}\right.$ day $\left.^{-1}\right), \mathrm{T}_{10}\left(1.79 \mathrm{~g} \mathrm{day}^{-1}\right), \mathrm{T}_{9}\left(1.71 \mathrm{~g}\right.$ day $^{-}$ $\left.{ }^{1}\right)$ and $\mathrm{T}_{4}\left(1.69 \mathrm{~g} \mathrm{day}^{-1}\right)$ were on par with $\mathrm{T}_{6}$. The lowest AGR $\left(1.10 \mathrm{~g} \mathrm{day}^{-1}\right)$ was observed in $\mathrm{T}_{1}$. The highest AGR $(1.92 \mathrm{~g}$ day $^{-1}$ ) was recorded in $T_{6}$ it might be due to better vegetative growth in terms of highest plant height, number of branches and total dry matter accumulation. The results were similar to the findings of Parshar et al. (2011) ${ }^{[12]}$ in kalmegh.

Table 1: Growth parameters in Tulsi (Ocimum sanctum L.) as influenced by integrated nutrient management practices

\begin{tabular}{|c|c|c|c|c|c|c|}
\hline Treatments & Plant height (cm) & Number of branches plant ${ }^{-1}$ & Leaf area $\left(\mathrm{cm}^{2}\right.$ plant $\left.^{-1}\right)$ & Leaf area index & $\begin{array}{c}\text { CGR } \\
\left(\mathrm{g} \mathrm{m}^{-2} \text { day }^{-1}\right)\end{array}$ & $\begin{array}{c}\text { AGR } \\
\left(\mathrm{g} \mathrm{day}^{-1}\right)\end{array}$ \\
\hline $\mathrm{T}_{1}$ & 81.23 & 37.53 & 3216.77 & 1.79 & 6.13 & 1.10 \\
\hline $\mathrm{T}_{2}$ & 84.73 & 39.77 & 3595.97 & 2.00 & 8.03 & 1.44 \\
\hline $\mathrm{T}_{3}$ & 85.83 & 40.73 & 3745.23 & 2.08 & 8.71 & 1.57 \\
\hline $\mathrm{T}_{4}$ & 87.83 & 42.53 & 4096.63 & 2.27 & 9.40 & 1.69 \\
\hline $\mathrm{T}_{5}$ & 90.83 & 45.73 & 4600.97 & 2.56 & 10.03 & 1.81 \\
\hline $\mathrm{T}_{6}$ & 91.83 & 46.77 & 4700.20 & 2.61 & 10.65 & 1.92 \\
\hline $\mathrm{T}_{7}$ & 83.47 & 38.50 & 3395.06 & 1.89 & 7.36 & 1.32 \\
\hline $\mathrm{T}_{8}$ & 86.83 & 41.50 & 3845.90 & 2.13 & 8.94 & 1.61 \\
\hline $\mathrm{T}_{9}$ & 88.83 & 43.67 & 4300.20 & 2.39 & 9.51 & 1.71 \\
\hline $\mathrm{T}_{10}$ & 89.87 & 44.53 & 4350.73 & 2.42 & 9.96 & 1.79 \\
\hline S.Em \pm & 1.99 & 1.94 & 226.12 & 0.13 & 0.48 & 0.09 \\
\hline CD @ 5\% & 5.91 & 5.76 & 671.84 & 0.37 & 1.43 & 0.26 \\
\hline
\end{tabular}

The fresh herbage yield per plant differed significantly due to integrated nutrient management practices (Table-2). Significantly, higher fresh herbage leaves yield (125.83 g plant $\left.^{-1}\right)$ was recorded in $\mathrm{T}_{6}$ followed by $\mathrm{T}_{5}\left(104.30 \mathrm{~g} \mathrm{plant}^{-1}\right)$, $\mathrm{T}_{10}$ (102.13 $\left.\mathrm{g} \mathrm{plant}^{-1}\right)$ and $\mathrm{T}_{9}\left(97.89 \mathrm{~g} \mathrm{plant}^{-1}\right)$. Whereas, significantly lowest fresh herbage yield was observed in $\mathrm{T}_{1}$ (61.06 $\left.\mathrm{g} \mathrm{plant}^{-1}\right)$ and $\mathrm{T}_{7}\left(62.74 \mathrm{~g} \mathrm{plant}^{-1}\right)$. The reason for increased fresh herbage yield might be due to mineralization of immobilized nutrients by vermicompost. Increased dosage of ' $\mathrm{N}$ ' helps the plant for profuse vegetative growth by causing synthesized photosynthates to get metabolically converted in to protein and amino acids and there by adding to production of more vegetative tissues. The phosphorous, a constituent of ATP and phospholipids, plays a role in various metabolic process of plants. ' $K$ ' aids in the effective conversion of photosynthates for better growth and ultimately yield of plant, these ' $\mathrm{P}$ ' and ' $\mathrm{K}$ ' were also supplied by vermicompost. Finally, Azotobacter and Azospirrilum ability to release phytohormones similar to gibberellic acid and indole acetic acid, which could stimulate plant growth, absorption of nutrients and photosynthesis. The results are in conformity with the findings of Hemalatha and Suresh (2012) ${ }^{[14]}$ in kalmegh.

The dry herbage yield was influenced by integrated nutrient management practices (Table-2). Significantly, higher dry herbage yield $\left(74.35 \mathrm{~g} \mathrm{plant}^{-1}\right)$ was recorded in $\mathrm{T}_{6}$ followed by $\mathrm{T}_{5}\left(61.45 \mathrm{~g} \mathrm{plant}^{-1}\right)$. Whereas, significantly lowest dry herbage yield was observed in $\mathrm{T}_{1}\left(17.65 \mathrm{~g} \mathrm{plant}^{-1}\right)$ and $\mathrm{T}_{7}(20.21 \mathrm{~g}$ plant $\left.^{-1}\right)$. Increase in dry herbage yield might be due to increase in fresh herbage yield and also integrated supply of nutrients encourages the several growth parameters ultimately helped in better absorption, utilization and translocation of nutrients by the plants results in higher fresh herbage yield in turn helps in increased dry herbage yield. These findings are in line with findings of Srivastava (2017) ${ }^{[8]}$ in kalmegh.

Table 2: Yield parameters in Tulsi (Ocimum sanctum L.) as influenced by integrated nutrient management practices

\begin{tabular}{|c|c|c|}
\hline Treatments & $\begin{array}{c}\text { Fresh herbage yield } \\
\left(\text { g plant }^{-1} \text { ) }\right.\end{array}$ & $\begin{array}{c}\text { Dry herbage yield } \\
\text { (g plant }^{-1} \text { ) }\end{array}$ \\
\hline $\mathrm{T}_{1}$ & 61.06 & 17.65 \\
\hline $\mathrm{T}_{2}$ & 72.41 & 29.21 \\
\hline $\mathrm{T}_{3}$ & 77.47 & 34.60 \\
\hline $\mathrm{T}_{4}$ & 86.85 & 43.62 \\
\hline $\mathrm{T}_{5}$ & 104.30 & 61.45 \\
\hline $\mathrm{T}_{6}$ & 125.83 & 74.35 \\
\hline $\mathrm{T}_{7}$ & 62.74 & 20.21 \\
\hline $\mathrm{T}_{8}$ & 81.72 & 38.90 \\
\hline $\mathrm{T}_{9}$ & 97.89 & 55.19 \\
\hline $\mathrm{T}_{10}$ & 102.13 & 59.76 \\
\hline $\mathrm{S.Em} \pm$ & 3.22 & 1.53 \\
\hline $\mathrm{CD}$ @ $5 \%$ & 9.56 & 4.56 \\
\hline
\end{tabular}

\section{Conclusion}

The finding of the present investigation clearly reveals that among the different treatments utilized to investigate the 
effect of integrated nutrient management on growth and yield of Tulsi (Ocimum sanctum L.) in Northern Dry Zone of Karnataka, $\mathrm{T}_{6} \quad\left(75 \% \mathrm{RDN}+\mathrm{RD} \mathrm{P}_{2} \mathrm{O}_{5}\right.$ and $\mathrm{K}_{2} \mathrm{O}+$ Vermicompost $5 \mathrm{t} \mathrm{ha}{ }^{-1}+$ Azospirillum $10 \mathrm{~kg} \mathrm{ha} \mathrm{ha}^{-1}+$ Azotobacter $10 \mathrm{~kg} \mathrm{ha}^{-1}$ ) showed superior performance for plant height, number of branches per plant, leaf area, leaf area index, CGR, AGR, fresh herbage yield per plant and dry herbage yield per plant.

\section{References}

1. Darrah HH. The cultivated basils. Buckeye Printing Company, Independence MO, 1980.

2. Devi UP. Radioprotective, anticarcinogenic and antioxidant properties of the Indian holy basil, Ocimum sanctum (Tulasi). Indian. J Exp. Biol. 2001; 39:185-190.

3. Hemalatha P, Suresh J. Impact of integrated nutrients on growth and yield of kalmegh (Andrographis paniculata). Int. J Agric. Sci. 2012; 8:168-170.

4. Kale RD, Bano K, Sreenivas MN, Bagyaraj DJ. Influence of warmcast (Vee Comp E Vas, 83) on the growth and mycorrhizal colonization of two ornamental plants. South. India. Hortic. 1987; 35:433-437.

5. Khalid M, Yadav BK, Yadav MP. Studies on the effect of integrated nutrient management on growth and yield attributes of radish (Raphanus sativus L.). Ann. Hort., 2015; 8(1):81-83.

6. Mandal S, Das DN, Dey K. Ocimum sanctum Linn - A Study on gastric ulceration and gastric secretiion in rats. Indian J Physiol. Pharmacol. 1993; 37:91-92.

7. Nadkararni AK, Nadkarni KM. Indian materia medica (Published by Popular Prakashan Pvt. Ltd., Bombay). Satyavati, G. V., Raina, M. K. and Sharma, M. (1976). Medicinal Plants of India (Published by ICMR, New Delhi), 1976.

8. Parshar R, Upadyay A, Singh J, Diwedi SK, Khan NA. morphological evaluation of kalmegh at different growth stages. J. Agric. Sci., 2011; 7(2):124-127.

9. Rahman KM, Sattar MA, Rahman GMM. Effect of fertilizer and manures on growth and yield of tulsi and pudina medicinal plant. J. Environ. Sci. nat. Resour. 2014; 7(2):13-16.

10. Raina NS, Rafiq M, Kishor SK, Sehgal S. Growth and yield of Ocimum sanctum in response to integrated nutrient management and plant spacing. Ind. J. Agron., 2013; 58(1):129-132.

11. Rashmi R. Integrated nutrient management in ashwagandha (Withania somnifera) M. Sc (Hort.) Thesis, Univ. Hort. Sci., Bagalkot, 2013.

12. Sarkar A, Lavania SC, Pandey DN, Pant MC. Changes in the blood lipid profile level after administration of Ocimum sanctum (Tulsi) leaves in the normal albino rabbits. Indian J Physiol. Pharmacol. 1994; 38(4):311312.

13. Satyavati GV, Raina MK, Sharma M. Medicinal Plants of India (Published by ICMR, New Delhi), 1976.

14. Srivastava A. Role of biofertilizers in combination with organic and inorganic nutrient sources in enhancement of growth in Kalmegh (Andrographis paniculata). Int. J. Adv. Res. Biol. Sci., 2017; 4(10):147-150. 